\title{
Conserving Nature Representation in Miyori no Mori Anime as a Teaching Media for Children's Moral Education
}

\author{
Wachyu Nur Fauzy ${ }^{1}$ \\ ${ }^{1}$ Faculty of Humanities, Diponegoro University
}

\begin{abstract}
This paper discusses moral education in Miyori no Mori anime. Moral education exists in this anime as a teaching about the importance of conserving nature. Miyori no Mori is an anime about Miyori, an 11 years old girl who moved from Tōkyō into the Komori countryside. Miyori, as the chosen guardian by the yōkai forest spirit of the Komori's forest, attempts to protect the countryside forest from a corporation that wants to build a dam inside the forest by destroying the whole forest area and jeopardizing the countryside. Representations of conserving nature in the anime can be observed through the conveyed moral values message explicitly and implicitly present in this anime. This paper aims to explain the conveyed messages of the Japanese moral education inside the anime for the importance of maintaining the core value belief by protecting the nature in between society to conserving nature. This paper methodology uses sociology of literature, the primary data object of this paper taken from the anime's characters interaction, behaviours, and conflicts by descriptive analyzing then reinterpret, represent, and conclude the analysis of moral education importance for conserving nature. The results suggested that Japanese's moral values and environmental ethics are represented.
\end{abstract}

\section{Introduction}

Today many people think that literature only covers social problems of human relations, such as social problems regarding psychology, religion and education. Many people do not realize that literature can be connected with environmental problems. Nowadays, many literary creators are aware of the importance of maintaining, preserving and preserving the environment. In creating a literary work, a literary creator can raise environmental issues. It is full of moral messages about how important and valuable the environment is to be kept, maintained and preserved so that life can continue.

Since childhood, people generally recognize literary works through written or oral form. Even if there are images in written literary works, there are generally only a few illustrative appearances. However, along with the times, this literary work in written and oral form has also experienced development. If at first, some written literary works received a few additional illustrations, gradually, the additional illustrations began to dominate, develop, and evolve to become new types of literary works; one example is anime. Even though anime is very different from the form of conventional written literary works, this work can still be classified as a literary work. This is because anime displays symbols, pictures, or illustrations in telling the story. Thus, this is in line with the assumption that literary works come from fairy tales or story content and can also be seen from a way of delivery. Therefore, based on this statement, it can be stated that anime can be classified as a part of literary work. 
Concern Concern and sensitivity of the creators of works towards environmental problems regarding the relationship between humans and environmental problems can be seen and felt recently by the increasing number of literary works that take up or raise themes and issues regarding the relationship between humans and environmental problems. One of the literary works that explore human relations with environmental problems is a Japanese anime titled Miyori no Mori by director Nizo Yamamoto, produced in 2007.

Miyori no Mori anime tells the story of the struggle of an 11-year-old elementary school boy named Miyori who tries to save a forest near Komori village where he was entrusted by his parents who live and come from Tōkyō. The forest that supports the life of Komori Village contains many wild animals and yōkai, which are forest guardian spirits who live in the forest. However, the forest plans to be drowned by bad people, namely representatives of a company that wants to turn the forest near Komori village into a dam. He teamed up with his new friends at school and yōkai (forest guardian spirits). Miyori and her friends try to prevent the plan of an evil person who wants to build a dam in the forest. Their efforts were carried out by searching for the existence of the golden eagle (イヌワシ), a wild animal protected by the Japanese government so that the wrong people can undo their plans.

This anime is very closely related to the environmental theme. The moral message about the importance of protecting, preserving and conserving nature is felt from the beginning to the end of the story. In addition, in this anime, the audience can learn about the importance of moral education for conserving nature. Nature conservation moral education aims to make humans aware of the environment. Environmental awareness is defined as expected to be able to shape human character who loves their environment.

The formation of a human character who loves their environment can be effectively carried out during childhood because childhood is the most critical period for a person to get lessons through moral education. It is a system of planting moral values in someone that includes awareness, understanding, caring. High commitment to implement these values, both towards the almighty God, himself, among humans, the environment, and society and the nation as a whole, to become a human being who can integrate and contribute both to social life. One of the ways to build human characters to love their environment is through anime media, such as moral education about moral values conveyed through the anime Miyori no Mori, especially around the concept of environmental ethics principles.

The higher a person understands the concept of environmental, ethical principles, the higher one understands how to care for, protect and preserve the environment. Thus those who do not care about their environment indirectly show their shared understanding of the concept of environmental ethics, which affects their participation in maintaining, protecting and preserving the environment.

This study will discuss the representations of environmental preservation in the anime Miyori no Mori as a medium for children's moral education to determine the relevance of planting an understanding of the concept of environmental ethics from a literary work through the sociology of literature approach and descriptive analysis method.

\section{Research Method}

This research is a descriptive qualitative literature study that describes the cultivation of understanding the concept of environmental ethics principles in moral education for Miyori no Mori anime through representations of environmental conservation efforts carried out by the main character of the anime Miyori no Mori. The method used is the sociology of literature method because what is discussed is things related to social problems, namely the problems of environmental issues regarding human relations regarding environmental problems. 
The sociology of literature study connects the factors that exist in the social environment of society with those outside literary works and those contained and contained in literary works. Sociology of literature is part of the science of understanding literary works that use sociology as an auxiliary science so that the sociology of literature is an interdisciplinary science. With the consideration that the sociology of literature is part of the science of understanding literary works, the analysis of literary works concerning society [1], According to Ratna, the model of sociology of literature analysis is divided into three types as follows:

1. Analyzing social problems which available in the literary works and relate them to reality; also called extrinsic aspects of literary works.

2. Analyzing social problems which available in the literary works by finding the relationship between their structures; dialectical.

3. Analyzing literature to obtain certain information [2].

Based on this statement, the assessment of moral education values regarding the cultivation of the concept of environmental ethics principles in the anime Miyori no Mori, which is within the scope of the sociology of literature study, follows the second and third analysis models.

\subsection{Moral Education}

Morals Morals are the basis for living as a nation and state. Many global problems also originate from a culture of moral values that have not been entirely taught and understood by all nations in the world. This follows Sutrisno's opinion, which states that moral is a reflection of the implications of the behaviour and attitudes of citizens in carrying out their duties and responsibilities as good citizens [3].

The factors of moral degradation, along with the times and technological advances, are caused by a person's low level of faith, honesty, and discipline, which comes from the influence of bad relationships in the surrounding environment, resulting in the loss of one's sense of social responsibility. To overcome the problem of moral degradation that will occur in the future, one of the efforts to prevent this can be overcome through moral education.

Moral education is away so that humans can understand and understand moral values, through human moral values is expected to develop a character to become an individual who can show behaviour to increase the capacity to think morally and make moral decisions in order to know what is the basis for acceptance and apply a value.

Moral values are an appreciation or quality from humans for something or things that can be the basis for determining other human behaviour because something or that can be fun, satisfying, interesting, useful, profitable, and is a belief system to harmonize and balance. The life that exists in this universe. Therefore, it fits for humans to create a civilization that upholds moral values.

The Japanese have a unique way to overcome moral degradation, namely, through character education; character education in Japan is taught through moral education. In Japanese, it is called doutoku, which is given at every level of school from elementary to high school. Through moral education or moral education, the character of the Japanese nation is created, which is known as a nation that is resilient, hardworking, persistent, honest, has a sense of tolerance, and a high sense of solidarity. This moral education is integrated into the educational curriculum and has become inseparable from other subjects [4]. Moral education integrated with the character education curriculum in Japan teaches moral values, including four things, namely as follows: 
1. Oneself relation moral value, includes:

a. Moderation (think independently and moderately).

b. Diligence (think hard independently).

c. Courage (think precisely with bravely).

d. Sincerity (think sincerely and cheerfully).

e. Freedom and Order (think freedom and orderly).

f. Self-improvement (understand yourself, act necessarily, and improve yourself).

g. Love for Truth (think to love yourself, find the truth for yourself in order to achieve the ideal life standard).

2. Other people relation moral value, includes:
a. Courtesy (act politely, speak and behave necessarily).
b. Consideration and Kindness (act considerately, kindly, compassionately).
c. Friendship (act to help the other).
d. Thanks and Respect (act respectfully by showing the gratitude).
e. Modesty (appreciate other people belief and differences).

3. Nature and noble relation moral value, includes:

a. Respect for Nature (treat nature and living being respectfully).

b. Respect for Life (treat all life respectfully).

c. Aesthetic Sensitivity (treat nature all life admirably).

d. Nobility (belief of nature power is an omnipotent present).

4. Society relation moral value, includes:

a. Public Duty (acknowledge the society obligation).

b. Justice (acknowledge the treatment for society must be without any discrimination, prejudice and injustice).

c. Group Participation and Responsibility (acknowledge the role in the society and must participate with any society duty).

d. Respect for Family Members (treat all senior citizen respectfully).

e. Contribution to Society (acknowledge the role into society and integrate with the society).

f. Respect for Tradition and Love of Nation (embrace the tradition value and act patriotic).

g. Respect for Other Culture (respect foreign culture by establishing international friendship) [5].

From the 4 theories above related to moral education in the anime Miyori no Mori, there are 2 moral values, namely nature and noble relation moral value as well as the society relation moral value is represented through conserving nature action that present in this anime.

\subsection{Concept of The Environmental Ethics}

The relation between the moral values of environmental ethics principles is connected to the moral values that exist in Japanese character education related to moral values around the relationship with nature and noble values and relations with society.

Humans are a part of nature that must maintain the balance of the ecosystem for its survival. So far, humans are not considered part of nature, so they are free to take advantage of everything in nature. Nature affects human life and vice versa, and humans are influenced by their nature. Humans exist in their nature and cannot be separated from it. Thus, nature becomes an essential part of human life to fulfil their daily needs [6].

Then, Sari stated that nature is one of the natural resources for all living things. Natural resources are an inseparable part of an ecosystem, an ecological system formed by an inseparable reciprocal relationship between living things and their nature. Massive 
exploitation of the existing natural resources without thinking about the long-term effects can be causing damage to nature [7].

By remembering the understanding that humans are part of nature and depend on nature for survival and knowing that all human actions will affect nature, it is necessary to cultivate an understanding of the concept of environmental ethics principles so that the sustainability of life can be maintained sustainably and protect all human actions towards nature in order to be harmonious so as not to destroy nature [8] destructively. The principles of environmental ethics, according to Keraf, are as follows:

1. Respect for nature;

2. Moral responsibility for nature;

3. Cosmic solidarity;

4. Caring for nature;

5. No harm principle;

6. Humble living and harmony for nature priciple;

7. Justice priciple;

8. Democracy principle;

9. Moral integrity priciple. [9]

The principles of environmental ethics regarding respect for nature, moral responsibility for nature, caring for nature, no harm principle, and humble living and hormony for nature priciple are a form of moral education to apply moral values about relationships with nature and noble values, as well as relations with the community.

\section{Results}

\subsection{Conserving Nature Representation Through Moral Values in Miyori no Mori Anime}

From the analysis results, the researcher assumed that the delivery of messages of moral values in the anime Miyori no Mori is divided into two types, namely direct delivery and indirect delivery. Directly, of course, in the form of an explicit explanation in a narrative text or dialogue between characters. Meanwhile, indirectly, the message of moral values is implicitly conveyed vaguely with the narrative text of the story or through characterization dialogue. It becomes implicit in interactions between characters, depicting story backgrounds, solving story conflicts, and illustrating symbols in the anime Miyori no Mori.

Some of the actions of implementing moral values of environmental ethical principles through representations of conserving nature is shown in this anime as follows:

1. Nature and noble relation moral value

In the Miyori no Mori anime, the depiction of a story set in a rural area is a message of moral values, namely respect for life and respect for nature through the application of moral values of environmental ethics principles regarding moral responsibility for nature, no harm principle, and humble living and harmony for nature principle.

a. Respect for nature:

Represented by the illustration of the houses of the residents in Komori village which are still simple, not built majestically as if they convey a message of moral values that as a human being have a moral obligation to respect the universe with everything in it because humans are part of nature and because nature has value in itself which is not can be separated from a human.

b. No harm principle:

Represented by the houses of the Komori villagers which are still simple as if they convey a message of moral values that human being should not harm nature 
unnecessarily which is manifested in caring behavior that takes the minimal form of nature, in the form of not taking actions that harm or threaten the existence of other living beings in this universe.

c. Humble living and harmony for nature priciple:

Represented by the simplicity of Komori's rural life, it conveys a message of moral values that human beings must understand themselves as an integral part of nature and make good use of nature. Living as it is in nature in order to follow the laws of nature, namely living by utilizing nature as needed, and means living by the demands of nature itself so that there is no need to be greedy, there is no need to take a lot from nature to make it exploit nature without limits.

The emergence of moral values of environmental, ethical principles towards nature regarding moral responsibility for nature, no harm principle, as well as humble living and harmony for nature principle because the villagers of Komori have love and concern for nature which is one direction, does not lead to another, without expecting anything in return. which is based not on the consideration of personal interests, but solely for the sake of nature.'

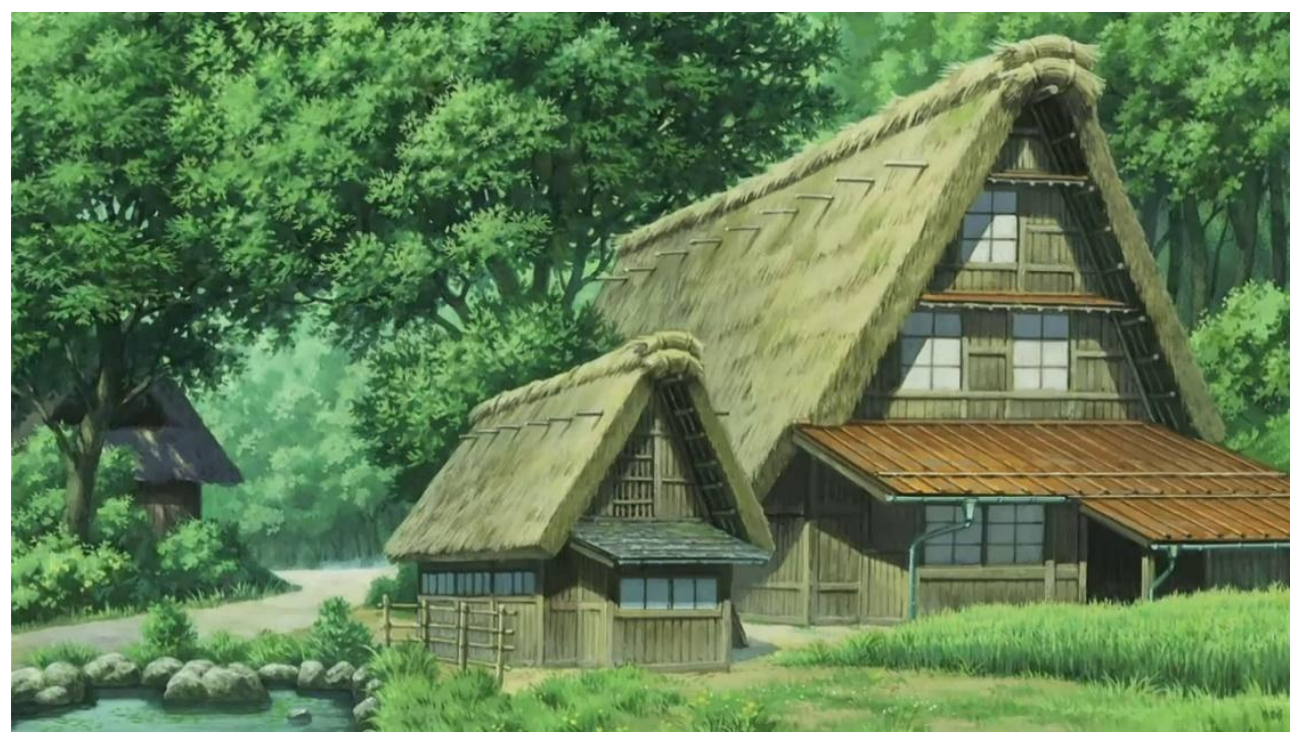

Fig. 1. The illustration of Komori villager houses in the Miyori no Mori.

2. Society relation moral value

In the Miyori no Mori anime, the part of events and illustrative depictions of symbols represented in this anime are a message of moral values regarding public duty, group participation and responsibility and respect for tradition and love of the nation through the application of moral values of environmental ethics principles of the moral responsibility for nature and caring for nature.

a. Moral responsibility for nature:

Represented by the conflict resolution event when Miyori and her friends work together to find the golden eagle so that the development plan by evil people who want to build a dam in a forest area can be cancelled, which will result in the sinking of Komori village as if conveying a message of value moral that a human being, as part of the universe, has the responsibility to protect and maintain this nature. This responsibility is individual and collective because nature demands that humans take the initiative, effort, wisdom, and real collective action to protect the universe and everything in it. 
b. Caring for nature

Represented by the symbols that are present in this anime regarding the typical decoration of Shinto beliefs in Japan, namely shimenawa and shide. Shimenawa and shide in the Shinto religious beliefs in Japan are believed to be a form of worship and respect by the Japanese towards an object because according to Shinto belief an object decorated with shimenawa and shide is believed to be the residence of a god so that its existence is considered sacred and should not be bothered or damaged, and disturbed its existence.

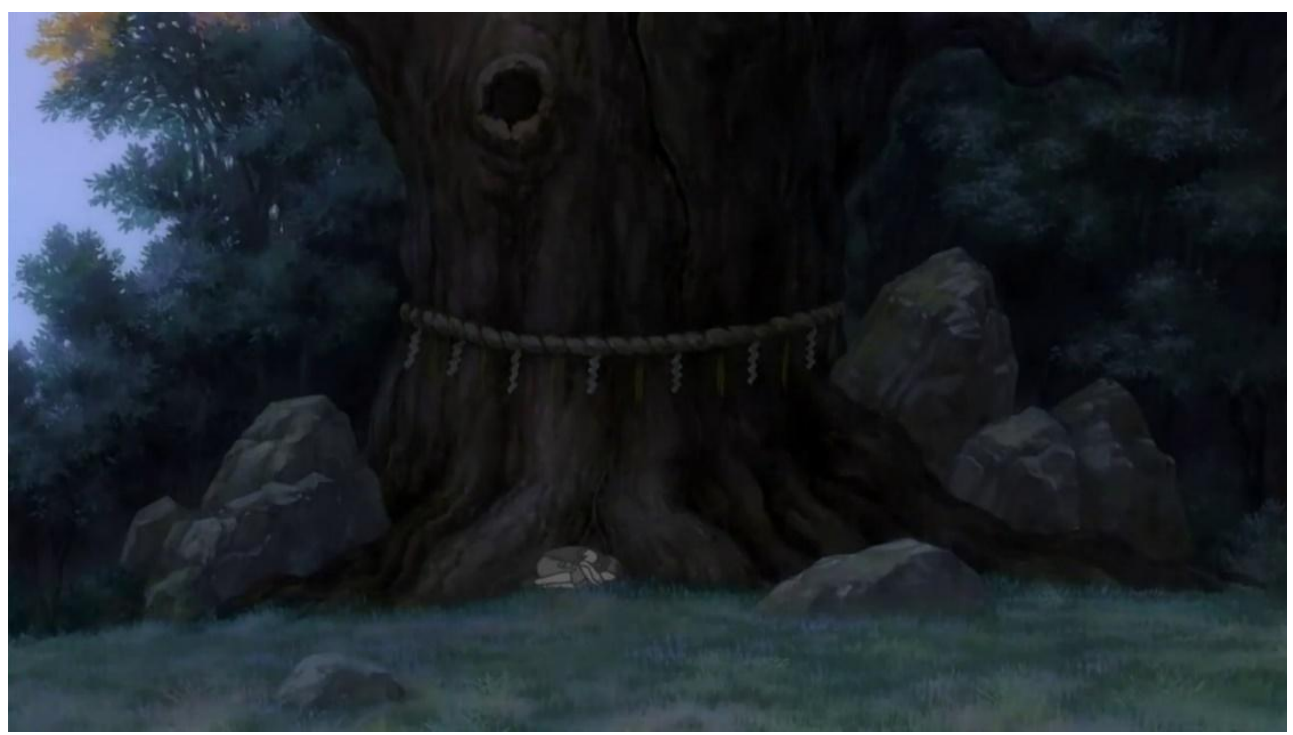

Fig. 2. The illustration of shimemawa and shide as a tree decoration in the Miyori no Mori anime.

The use of decorations shimenawa and shide placed on the tree seems to convey messages of moral values in order to give the understanding that nature does animate, but not only in a physical sense, but also in a mental and spiritual sense. By loving and caring for nature, humans will also become stronger and more and more manifest themselves as mature persons such as becoming calmer, more peaceful, and full of compassion, as the characteristics of nature show, namely the vast, lonely, and abundant nature of nature which shows the nature of nature, namely accept and accommodate diversity and diversity.

The depiction of illustrations and fragments of events contained in the anime Miyori no Mori through representations of environmental preservation is an effort to educate the audience with moral values about relationships with nature and noble values, as well as relationships with society because they reflect the moral values of environmental, ethical principles. Regarding respect for nature, the principle of moral responsibility, compassion and concern for nature, the principle of not causing harm to nature, and living simply and in harmony with nature so that we as humans must instil moral values, the principles of environmental ethics as the basis for the moral compass of life our daily lives in order to be able to protect, maintain and preserve the only environment we live in, namely the nature around us. 


\section{Conclusion}

Moral education, through the delivery of messages of moral values regarding the application of environmental, ethical principles in life is act as a guide and guidance for human behaviour when dealing with nature so that it does not cause damage to the balance order and the sustainability of the life in this universe. In the Miyori no Mori anime, moral education through the delivery of messages of moral values regarding the application of the principles of environmental ethics available in this anime is the delivery of messages of moral values regarding the nature and noble relation moral value as well as society relation moral value is based on Japanese character education.

There are five principles of environmental ethics represented from the anime Miyori no Mori, namely respect for nature, moral responsibility for nature, caring for nature, no harm principle, and humble living and harmony for nature principle. The results of the representation of the delivery of moral values through the five principles are from the depiction of the background of the story, the symbols such as shimenawa and shide display ofas well as the conflict resolution in the story about saving the forest and the settlements of Komori villagers from the threat of bad people who plan to drown the forest and residential areas. Komori village through a dam construction design in a forest area near the Komori village. The representation of environmental preservation can be achieved by Miyori along with the support and assistance of yōkai, the guardian of the forest and forest creatures, friends, family, and Komori villagers.

\section{References}

1. Noviana, F, Moral values in Hayao Miyazaki's Spirited Away: A sociology of literature approach, Humanika, 27, 1 (2020)

2. Ratna, N K, Teori, Metode, dan Teknik Penelitian Sastra, Yogyakarta: Pustaka Pelajar, (2008)

3. Sutrisno, Internalisasi pendidikan moral pada perguruan tinggi di Jepang, Jurnal Civics: Media Kajian Kewarganegaraan, 17, 1 (2020)

4. Ibid

5. Mulyadi, B, Model pendidikan karakter dalam masyarakat Jepang, Journal Izumi, 3, 1 (2014)

6. Sari, A I, Hubungan ekologi dengan pelestarian lingkungan, Jakarta: Universitas Negeri Jakarta, (2020)

7. Ibid

8. Keraf, A S, Etika Lingkungan Hidup, Jakarta: Penerbit Buku Kompas, (2010)

9. Ibid

10. Nippon Animation, Fuji TV, Miyori no Mori, (Television Broadcast, Tokyo: Public Broadcasting Service, 2007) 